„Bohemistyka” 2019, nr 1, ISSN 1642-9893

Alesia I. FrANTCEVA

DOI: $10.14746 /$ bo.2019.1.5

St. Petersburg State University

\section{Fragmentary Russian-Czech-English lacunarity of the lexeme Tower on the material of dictionaries}

Keywords: linguistics, contrastive grammar, cultural linguistics, lacunarity, Russian language, Czech language, English language

\section{Abstract}

In this article we consider the method of contrastive analysis of башня (tower in Russian) lexeme, where the Russian language will be the source language, and the Czech and English languages will be the languages of comparison. In the study we will describe the comparison of the data of etymological dictionaries in three languages.

The aim of this comparative analysis is discovering similarities and differences in the sub-systems of three languages.

The central concept of contrastive linguistics is the notion of interlingual correspondences - units of different languages having similarities in composition of semes. Formally, there are three types of correspondences: linear correspondences, vector correspondences, lacunae. In this article we will consider one of them - fragmentary lacunarity.

When we speak about linguistic research that is conducted in several languages at a time we need to mention the comparative historical method of researching a language and the very concept of language comparison. Comparative historical linguistics dates back to Germany of the beginning of the 19th century and it is associated with the names of F. Bopp and J. Grimm, as well as with the names of R. Rask (Denmark) and A.K. Vostokov (Russia).

Comparative historical linguistics is at the core of the comparative linguistics where the comparison is used for two reasons: in order to discover common patterns and to find out historical methods.
Сравнительно-историческое языкознание представляет собой область языкознания, объектом которого является установление соотноения между родственными языками и описание их эволюции во времени и пространстве (Стернин 2007, p. 13)

Contrastive linguistics started its formation in the 1960-s and developed into a separate discipline in the last quarter of the 20th century.

For contrastive linguistics the genetic affinity of compared languages is not of fundamental importance, as the contrastive method allows to study various languages. The native and foreign languages are most commonly used for contrastive research. The terms that are normally used are the following: the source language - a language that is the core of a research, and the compared language, that is being compared to the source language. At the same time, analysis in any direction is allowed. The mother tongue may or may not act as the source language, as it is also possible to compare foreign languages with each other. However, it is important to research units of one language with its potential analogues in another language.

Контрастивная лингвистика выступает как одна из ярких и эффективных форм связи между фундаментальной теоретической лингвистикой и прекладными аспектами языкознаниями (Стернин 2007, p. 15).

The Russian scientist L.V. Shcherba as the first considered contrastive language studies of utmost importance not only for improving foreign language studies, but also for a more fundamental understanding of one's mother tongue (Щерба 1974).

Various points of view on the necessity of separation between comparative and contrastive linguistics exist. V.N. Yartseva uses the term „comparative linguistics” (Ярцева 2007, p. 13).

She highlights that the second term is used more widely due to its greater conventionality, pointing out at its distinctive (contrastive) features.

V.M. Mokienko considers this separation rather important

[...] ибо первый термин подчеркивает направленность прежде всего на дифференциальные особенности сопоставляемых языков, а вто- рой на сам процесс 
сопоставления, для которого важны как межъязыковые различия, так и сходства. Для советского языко- знания более характерен второй тип сопоставительных исследований (Мокиенко 1987, р. 47).

The concept of cross-language correlations is at the core of contrastive linguistics, when units of different languages have similarities in their component composition. Based on the system of I.A. Sternin there exist three types of correlations:

- Linear correlations $(1: 1)$ : the unit of the source language corresponds to only one unit of the compared language;

- Vector correlations $(1: \mathrm{N})$ : the unit of the source language corresponds to several units of the compared language;

- Lacuna $(1: 0)$ : the unit of the source language does not correspond to any unit of the compared language.

\section{Classification of the compared lexemes}

We will use this classification to compare lexeme башня (tower in Russian) in three languages: Russian, Czech and English. One of the component meanings of the lexical unit башня in Czech and English languages is 'prison' and it does not have correlation in the Russian language. In this case we are facing with lacunarity. We have a lacuna in our mother tongue (Russian), that can be classified as the cross-language lacuna (there also exist intra-language lacunae, when there exist no units inside the paradigms of the same language, for instance, when there are no words with the opposite meaning).

Let us consider motivated and unmotivated lacunae. The first group of lacunae can be explained by the absence of a corresponding object or phenomenon in the national culture, while the second group, unmotivated lacunae, do not relate to the absence of a certain phenomenon or object, as such realities exist in the culture, but there is no name for them.

We come across lacunarity in the notations of realities of a certain nation, such as their clothing, food, housing, musical instruments, etc. On the other hand, as the lexeme that we are researching has several centuries of history and a long tradition of using, we can only consider component lacunarity.

When we are researching башня lexeme in Russian, Czech and English we identify lacunarity with the help of the comparative etymological analysis based on the use of etymological dictionaries, that will indicate the languages where the initial meaning of the concept survived.

\section{Etymological analysis of lexeme башня in Russian as a source language}

Etymological analysis allows us to study the mechanisms of the concept formation and find out initial associations, linked to it. The concept of the tower is primarily associated with the high defensive architectural structure.

In Russian there are two synonyms: башня (modern) and вежа (old Russian). We will study both these lexemes. There also exists another ancient word that is almost never used in the current language - башня. What we know about the etymology of these words?

We will start with the etymology of the word башня (баштя). According to Этимологический словарь русского языка, том 1, a(1964, p. 139), the word башня was borrowed from the dialect of the Pskov region through Polish word bazsta and Czech bašta, from Italian bastia that means bastion, fortification.

It was mentioned for the first time in the 1st Pskov Chronicle and it was used widely in the 17th century, the ending of the word was modified in line with the Slavic suffix -nja. The older form of the ancient Russian бamma was used by Nestor Iskander in the 16th century.

Словарь русского языка XI-XII вв. gives a brief entry for the word бamma, but it, nevertheless, allows us to get to know more about this concept. The word has one meaning:

Башта - сущ. ж. р. Башта - то же, что башня (в первом знач. п. 2.1.5.). И поставила башьту шти саженъ вверхъ, и взнесли на нее много наряду, полуторные пищали и затинные. Николаевская летопись, XIII в. (Словарь русского языка XI-XII вв. 1975, p. 83). 
There is no separate entry for the word башта in Этимологический словарь русского языка (1964, s. 139), but it is mentioned in the entry for башня. It says that башта is the earlier form in the ancient Russian language that was mentioned by Nestor Iskander in the 16th century.

Thus, the initial meaning of the word is attributed to the concept of 'укрепление, оборонительное сооружение' (fortification).

Let us consider the etymology of the word unit вежа. According to Этимологический словарь русского языка (1964, р. 139) the earliest mention of the word dates back to the year 898 in the meaning 'стать станом, расположиться кибитками на кочевье. Стати вежами' (to form a camp). Later, in the year 1097 the word is used in the meaning 'осадное сооружение' (construction for siege). The next meaning dates to the year 1186 'стан, кочевье' (camp, camping ground). For the year 1190 it is 'крепостное сооружение, башня' (fortification, tower).

Then in 14th century follows 'легкая жилая постройка (кочевая кибитка, палатка, шатер)' (light weight residential building; nomadic tent). In the 15 th century there is 'рыболовное угодье с постройками, тонья' (fishing ground with buildings) and in the 16th century we meet 'хозяйственная постройка' (household building).

In the modern Russian language we very seldom use the word вежа and here we can refer to the lacunarity of its meaning. Nevertheless, the word has 5 different semantic meanings according to Словарь русского языка XI-XII вв. (1975, p. 83). Moreover, this word has three homographs.

Вежа, ж.:

- легкая жилая постройка (кочевая кибитка, палатка, шатер);

- мн. стан, кочевье;

- крепостное сооружение, башня, осадное сооружение

- хозяйственная постройка;

- рыболовное угодье с постройками, тоня (Словарь русского языка XI-XII вв. 1975 , p. 83)
We can see that the semantics of this word develops from the meaning of a nomadic tent, camping ground, construction for siege to embrace the meaning of a household building. Probably the so-called towers, movable siege constructions, were at the first used during town sieges and they somehow reminded tents of nomads. Initially the word вежа was similar to башня.

Словарь русского языка XI-XII вв. (1975, p. 83) contains two more entries where вежа (feminine) means 'eyelid' and вежа (masculine) - 'knowledgeable person with experience in something'.

Этимологический словарь русского языка (1964) contains two entries for this word. We will start with the most relevant for us:

Вежа-встречается только в древне-русском въжа 'шатер, кибитка, башня' (Повесть временных лет). Украинская вежа 'башня' (ввиду наличия е заимствованного из польского языка), болгарская вежа 'башня', словенская véža 'сени, передняя', древне-чешская vež, veža, словацкая vež, польская wieža, лужская wjaža, jaža 'дом’. Из праславянского veža, vezia (русское везу), то есть 'дом-повозка' на полозьях или колесах. Значение 'дом-повозка, кибитка' перешло в ‘шатер’, откуда ‘передвижная башня’, ‘башня’.

Вежа, сущ. м.р. - только в древне-русском 'знающий, сведущий', современное невежа, в церковно-славянском - невежда 'неученый'. Сюда 'вежливый' (Этимологический словарь русского языка 1964, р. 139).

We can see that there exist certain rules associated with the use of башня (башта) and вежа lexemes in Russian and that some of their meanings are lost in the modern language, so that we can speak about their lacunarity.

Russian etymological dictionaries give us a detailed history overview of the origin of the word башня in the Russian language. In our etymological analysis we encountered an earlier form of the word, башта, and its synonym, вежа. We found out that all these words contain at least one meaning that relates to the architectural structure. It also has the meaning of the defensive military structure that is constructed in order 'охранять, оборонять' (to watch over and protect).

Thus, the comparison of the vocabulary of the related Slavic languages allows us to make assumptions about how the linguistic image of 
the world of our ancestors looked like. The lexeme башня осcupied a certain place in the linguistic image of the world of ancients Slavs that might have been more important for them than for us due to the number and type of wars that they were fighting at. It is probable that the meaning 'охранять, оборонять' (to guard, to defend) was included in the initial etymology of the word.

Let us perform the etymological analysis of this word in the Check language.

As we know, Russian and Czech languages belong to the same group, but to different branches of Slavic languages, Russian language is in the east Slavic branch and Czech language in the west Slavic branch. Apart from that, each of these languages has witnessed enormous changes throughout history. Nevertheless, the basis of all Slavic languages is the same. Therefore it makes sense to address related languages in order to study the concept and track its development in the history and culture.

\section{Etymological analysis of lexeme věž in Czech as a language of comparison}

In the modern Czech language there exist two synonyms: věž and $b a s ̌ t a$. Let us see the etymology of these concepts and track the lacunarity of some of their meanings.

According to Slovník spisovného jazyka českého (1971) feminine noun bašta was borrowed from Italian. However, the information from Etymologický slovník jazyka českého (1971, p. 47) is contradictory. V. Machek writes there that the word bašta already existed in the Ancient Czech Language and from there it was borrowed by Polish, while the word that was taken from Italian actually means the name of a dish that goes under a separate entry as an homonym.

According to Etymologický slovník jazyka českého (1971), this word stands for a 'certain part of fortification' and it means 'reliable protection in a figurative sense'. In the language of fishermen it means 'a house of a person who takes care after the fish', that is 'opevnění ochrana před nepovolanými’. Apart from that, bašta might have meant 'the canopy for sheep on a mountain pasture'. Thus, the etymology of the word again contains the meaning of 'protect, guard' (Etymologický slovník jazyka českého 1971, p. 124).

It would not be right to say that the word is outdated, it is still used in Czech, but more rarely than the word věz. Therefore we cannot talk about lacunarity in this case.

Let us track the etymology for věž.

$V \check{z} z \check{z}, e-n$. f. According to the entry from the Etymologický slovník jazyka českého (1971) the word věža existed in the Church Slavic language. Thus, this lexeme sustained its original graphics in Czech as well as some other Slavic languages. In Polish still exists the word wieža, in Croatian - vieža (meaning kitchen), in northern Russian dialects $-v e \check{z} a$ (meaning yurt). All these lexemes are written in a similar way, but their meaning is different. Each of them relates to one of the past meanings (Etymologicky slovnik jazyka českého 1971, p. 688).

As V. Machek described, the word initially meant a small construction, tent, the house of nomads, shelter (from this meaning derives the word юpma in northern Russian dialects). In reality it was a small house, hut, cart-house. There is an evidence that such houses on the wheels were used by nomads.

Balkan tribes used sledges instead of wheels. In the summertime these movable houses were transported closer to pastures and used for the protection of farmland and in the winter they were returned back to the main house.

In German exists the word svaigh - with Proto-European roots. Its etymology is closer to the ancient Russian nриют (shelter) which means 'to hide' and 'to guard'.

In Czech we find an expression that combines both words - Baštovni věž with the meaning of a bastion, a tower on the fortified wall or a tower in the fortified castle.

The word věž is used in Czech both in the direct and figurative meanings. Apart from the usual meaning of the architectural construction it is used in a different context. This lexical unit can exist both as a distinct expression and in the idiomatical phrases. It is often used with 
adjectives, indicating the purpose of a construction. The variety of meanings of the word indicates how wide is its use in the language. We can see that the image of the world in this lexical unit is not only saved in its original meaning but also it acquired new modern meanings which proves its mobility and vitality in Czech.

By using etymological analysis of synonyms in Slavic languages we may assume that once there existed several lexical forms for one concept, the so-called semantic synonyms, but later, under the influence of various processes in each language, they got transformed into different graphic images. It indicates the presence of lacunaruty in related Slavic languages.

The reasons for this transformation are different, for examples, various cultural influences and many others. At the same time the meaning of the lexeme in these languages still bears some similarities.

\section{Etymological analysis of lexeme tower in English as a language of comparison}

In order to make our research look more complete we would like to take the language from another language group and compare the Russian word башня and Czech word věž with the English lexeme tower.

English belongs to the German group of the Indo-European language family. Analytical forms prevail in English, while Russian and Czech are fusional languages. This will be of interest to us, first of all, for the comparative analysis of word-formative nests.

We will turn again to the methodological analysis of the lexeme with the main stage that implies a historical etymological analysis of the lexeme.

According to The Oxford Dictionary of English Etymology (1966, p. 456) the word tower was first mentioned in the 12th century.

This historical epoch is known under the name of the Norman Conquest. The Norman dynasty of English kings was founded by the Duke Wilhelm the Conqueror in 1066. Normans invaded Great Britain as the bearers of the French language, French culture (although with so- me particularities) and the French feudal state structure. Thus, with the conquerors, the French language or, more precisely, its northern, normandic, dialect appeared and influenced dramatically English. This period of history is associated with numerous borrowings from French.

In Middle English we find the unit tūr, later tour and town in English-Normandic. This graphical form is more in line with the present day spelling of the word and it resembles the modern English word town (city). This allows us to conclude that these lexical units have the same semantics and that one structure was part of another, in other words, cities at that time were walled with towers.

The Etymological dictionary of the English language (1956, p. 652) contains the following entry:

Tower, sb. - a lofty building, fort, or part of a fort. (F.,-L.) Spelt tur in the A.S. Chron. an 1097 - O.F. tur, later tour, a tower. Cot.-Lat. turren, acc. O.F. turris, a tower. G.K. tupois, a tower, bastion. We also find Gael. torr, a hill or mountain of an abrupt or conical form, a lofty hill, eminence, mound, tower, tor, a conical hill, a word of Celtic origin. In the Gael. Torr be not borrowed from Latin, it is interesting as seeming to take us back to a more primitive use of the word, viz. a hill suitable for defence" (The Etymological dictionary of the English language 1956, p. 652).

Middle English language period lasted from 1066 to 1485 . After the invasion of the Norman feudal lords in 1066 a new important lexical layer of the so-called normanisms, the words borrowed from the Norman French dialect of the Old French language and used by the invaders, was introduced into the Old English language. For a long time in England the Norman French remained the language of the church, the administration and the nobility. But the number of the conquerors was not large enough to keep their language unchanged in this country. Gradually middle and small landowners who belong to the Anglo-Saxon population of the country acquire greater importance. Instead of the dominance of Norman French a kind of the ,language compromise" is forming and, as a result, a language that is close to what we now call English.

Modern French contains the following feminine word: 
(a) tour, $\mathrm{f}$

watchtower - tour de guet

(b) military, naval tourelle, $\mathrm{f}$

rotating tower - tourelle pivotante

gun turret - tourelle (blindée) (https://www.abbyy.store/all-products/dictionaries).

From the graphic representation we can see that these words are related. It proves once again that the English tower was borrowed from French. Although the graphic form tower has nothing in common with the Slavic lexemes, its defending meaning is also present in the English language.

At the same time it bears no other meanings that we were talking about above, which allows us to conclude that these meanings are lacunar in English.

The history of the origin of the word helped us to analyse the mechanisms of the formation of lexical meanings and discover the primary associations linked to it. For the lexeme башня in Czech, English and Russian it is, first of all, the representation of a high defensive architectural construction.

By researching the etymology of lexemes башня, vе̌ž and tower we found out that they have been present in the languages for many centuries and, at the same time, they are not obsolete and used now actively. When we tracked the history of the lexemes we accidently discovered two synonymous language units in Russian, башня and вежа, bašta in Czech. But, due to some historical or cultural reasons, they are rarely or never used in modern Russian and Czech languages. In this case, it is reasonable to speak of lacunarity of meanings.

The history of the English lexeme tower indicated us similarity and affinity with the French word tour.

One of the stages of the component analysis allows us to find semes of the main lexeme, башня, that, depending on the context, give us an idea of the conceptual features that form the core of the concept we have been studying.

In the conclusion it should be noted that by analysing the entries of the etymological dictionaries in Russian, Czech and English we were able to track the way of the lexeme башня in the history of languages and describe it together with the changes and influences that it has experienced. Among one of the key results of this historical influence has been the lacunarity of lexical meanings of lexeme башня in languages researched: Russian, Czech and English.

\section{Bibliography}

An Etymological Dictionary of the English Language by the Rev.Walter, W.Skeat, 1956, Oxford, MDCCC LXXXII.

Etymologický slovnik jazyka českého, 1971, ed. V. Machek, Praha.

Https://www.abbyy.store/all-products/dictionaries.

Slovník spisovného jazyka českého, 1971, ed. B. Havranek, Praha.

The Oxford Dictionary of English Etymology. Onions.C.T., 1966, Oxford.

М о к и е н ко В.М., 1987, Сопоставление в теории и практике преподавания русского языка как иностранного. „Русский язык за рубежом”, № 5.

Словарь русского языка XI-XII вв., 1975, ред. Г.С. Бархударов, Москва.

С т е р н и н И.А., 2007, Контрастивная лингвистика. Проблемы теории и методики исследования, Москва.

Щ е р б а В.Л., 1974, Преподавание иностранных языков в средней иколе. Общие вопросы методики, Москва-Ленинград.

Этимологический словарь русского языка, 1964, ред. М. Фасмер, т. 1 (А-Д), Москва.

Я р ц е в а В.Н., 1981, Контрастивная грамматика, Москва. 